\title{
Effect of metformin on the proliferation, apoptosis, invasion and autophagy of ovarian cancer cells
}

\author{
GE ZOU, JIE BAI, DANDAN LI and YAN CHEN \\ Department of Obstetrics and Gynecology, North China University of \\ Science and Technology Affiliated Hospital, Tangshan, Hebei 063000, P.R. China
}

Received July 2, 2018; Accepted April 26, 2019

DOI: $10.3892 /$ etm.2019.7803

\begin{abstract}
The present study evaluated the effect of metformin on the SKOV3 ovarian cancer cell line and investigated the underlying mechanism. The inhibitory rate of SKOV3 cells was analyzed by MTT assay. SKOV3 cell apoptosis rate was quantitatively measured using flow cytometry. The effect of metformin on intracellular autophagosomes was observed using electron microscopy. The migration and invasion capabilities of SKOV3 cells were assessed by cell scratch test and Transwell assay. Results demonstrated that. the proliferation rate of SKOV3 cells was significantly inhibited in a time- and concentration-dependent manner following treatment with different concentrations of metformin for 24,48 and $72 \mathrm{~h}$. The number of migratory cells significantly decreased with increasing concentrations of metformin. The administration of metformin also promoted autophagy of ovarian cancer The expression level of microtubule associated protein 1 light chain 3- $\alpha$ protein was markedly upregulated. The mRNA expression level of metastasis-associated 1 (MTA1) was significantly downregulated following metformin treatment. In conclusion, metformin intervention suppressed SKOV3 proliferation and induced apoptosis in a concentration-dependent manner. Metformin also inhibited the invasion and migration of SKOV3 cells. It was hypothesized that the underlying mechanism of metformin's effect may involve MTA1 downregulation.
\end{abstract}

Correspondence to: Dr Yan Chen, Department of Obstetrics and Gynecology, North China University of Science and Technology Affiliated Hospital, 73 Jianshe South Road, Tangshan, Hebei 063000, P.R. China

E-mail: yanchen17@sina.cn

Abbreviations: AMPK, adenosine monophosphate-activated protein kinase; mTOR, mammalian target of rapamycin; MAP1LC3A, microtubule associated protein 1 light chain 3- $\alpha$; MTA1, metastasis-associated 1

Key words: ovarian cancer, SKOV3, metastasis-associated 1

\section{Introduction}

Ovarian cancer forms in or on an ovary leading to invasion or spreading of abnormal cells to other parts of the body (1-3). Initially, there may be no or only minor symptoms which may become more noticeable as the cancer progresses. Typical symptoms can include bloating, pelvic pain, abdominal swelling and loss of appetite. Common metastasis sites include the lining of the abdomen, lymph nodes, lungs and liver (4). Diagnosis of ovarian cancer starts with a physical examination consisting of a pelvic examination, a blood test for cancer antigen 125 and alternative markers, and trans-vaginal ultrasound. A recto-vaginal examination is occasionally necessary to help plan a surgery. The diagnosis must be confirmed with surgery to inspect the abdominal cavity, take tissue sample biopsies for further analysis, and to identify any cancer cells in the abdominal fluid. These analyses can identify whether an ovarian mass is benign or malignant. Surgery depends on the extent of nearby tissue invasion. Chemotherapy may be used post-surgery to treat any residual disease (5)

Metformin is a first line antidiabetic medication that lowers insulin levels. It displays anticancer effects since insulin has mitogenic and pro-survival effects with tumor cells often expressing high levels of the insulin receptor (6). Metformin exerts its direct, insulin-independent action through 5' adenosine monophosphate-activated protein kinase (AMPK) activation, which decreases cancer cell mammalian target of rapamycin (mTOR) signaling and protein synthesis (7) The indirect insulin-dependent effects of metformin reduce fasting blood glucose and insulin levels. In addition, metformin is widely commercially available with minimal adverse effects $(3,5,8)$.

In the present investigation, the epithelial ovarian cancer cell line SKOV3 was selected to evaluate the effects of metformin on proliferation, apoptosis, invasion, migration and autophagy. In addition, the influence of metformin on the expression levels of microtubule-associated protein 1 light chain 3- $\alpha$ (MAP1LC3A) and metastasis-associated 1 (MTA1) was also assessed.

\section{Materials and methods}

Cell culture and drug treatment. Human ovarian cancer cell line SKOV3 (Shanghai Bioleaf Biotech Co., Ltd.) was cultured 
in high-glucose DMEM (Gibco; Thermo Fisher Scientific, Inc.) containing $10 \%$ fetal bovine serum (Clark Bioscience). SKOV3 cells were experimented with in the logarithmic phase. SKOV3 cells were divided into the control group using complete medium, and 2.5, 5 and $10 \mathrm{mmol} / 1$ metformin (Sigma Aldrich; Merck KGaA) experimental groups. All experimental procedures were repeated three times.

MTT assay. SKOV3 cells were inoculated into 96-well plates at a density of $1 \times 10^{4}$ cells/well and cultured in culture medium with different concentrations of metformin $(0,2.5,5$ and $10 \mathrm{mmol} / \mathrm{l}$ ) for $48 \mathrm{~h}$. Samples were then supplemented with $20 \mu \mathrm{l} \mathrm{MTT}$, cultured for $4 \mathrm{~h}$ then $200 \mu \mathrm{l}$ DMSO was added. The optical density (OD) value was detected at a wavelength of $490 \mathrm{~nm}$. The formula used to calculate inhibitory rate of cell cytotoxicity was as follows: Inhibitory rate of cell cytotoxicity $=1-(\mathrm{OD}$ value in the experimental group/OD value in the control group) $\mathrm{x} 100 \%$.

Flow cytometry. SKOV3 cells were inoculated into six-well plates at a density of $5 \times 10^{5}$ cells/well then cultured in medium with different concentrations of metformin $(0,2.5,5$ and $10 \mathrm{mmol} / \mathrm{l}$ ) for $48 \mathrm{~h}$. Cells were digested and centrifuged at $200 \mathrm{x} \mathrm{g} / \mathrm{min}$ for $5 \mathrm{~min}$ and resuspended in $500 \mathrm{ml}$ buffer solution. Samples were supplemented with $5 \mu$ l Annexin fluorescein isothiocyanate (BD Biosciences) and $5 \mu \mathrm{l}$ propidium iodide (BD Biosciences) then incubated in dark room at room temperature for $15 \mathrm{~min}$. Apoptotic cells were analyzed using a flow cytometer and CellQuestPro 5.1 software (BD Biosciences).

Electron microscopy. SKOV3 cells were cultured in $100 \mathrm{ml}$ culture plates supplemented with 0 or $10 \mathrm{mmol} / 1$ metformin for $72 \mathrm{~h}$. Treated cells were collected and supplemented with $2.5 \%$ glutaraldehyde (Sigma-Aldrich; Merck KGaA) at $4^{\circ} \mathrm{C}$ overnight. Cells were fixed in $1 \%$ osmic acid at $4^{\circ} \mathrm{C}$ for $2 \mathrm{~h}$ then dehydrated in $50 \%$ acetone for $15 \mathrm{~min}, 70 \%$ acetone for $15 \mathrm{~min}, 80 \%$ acetone for $15 \mathrm{~min}, 90 \%$ acetone for $15 \mathrm{~min}$ and finally $100 \%$ acetone for $15 \mathrm{~min}$. Ethoxyline resin was mixed with $100 \%$ acetone at a ratio of 1:1 and cells were embedded in the resin overnight at $37^{\circ} \mathrm{C}$. The following day, samples were sectioned into slices of 50-60 nm thickness, stained with uranium acetate (Amresco, LLC) for $10 \mathrm{~min}$ at room temperature in the dark. After washing with $\mathrm{H} 2 \mathrm{O}$, samples were stained with lead citrate (Amresco, LLC) for $10 \mathrm{~min}$ at room temperature again. The status of autophagy was observed using transmission electron microscope.

Cell scratch test. SKOV3 cells were inoculated in 6-well plates and cultured in serum-free medium for $12 \mathrm{~h}$. When the cell confluence reached $\sim 90 \%$, a $20 \mu$ l pipette tip was used to scratch the monolayer then samples were rinsed with PBS three times to remove non-adhered cells. Images were taken at 0,24 and $48 \mathrm{~h}$ in 5 random fields for each group. The distance of cell migration was calculated by subtracting the scratch width at $0 \mathrm{~h}$ from the scratch width at 24 and $48 \mathrm{~h}$, using ImageJ 142-jdk6 (National Institutes of Health).

Transwell chamber assay. Transwell upper chamber membrane (Costar; Corning, Inc.) was treated with Matrigel for $2 \mathrm{~h}$ at $37^{\circ} \mathrm{C}$ (BD Biosciences). Following cell culture for $72 \mathrm{~h}$, the cell concentration was adjusted to $1 \times 10^{4}$ cells/well then $100 \mu \mathrm{l}$ cell suspension was added to the upper chamber and $600 \mu \mathrm{l}$ suspension, without cells containing, $10 \%$ fetal bovine serum was added into the lower chamber. Following cell culture for $15 \mathrm{~h}$, the cells were collected, washed in PBS twice and fixed in $4 \%$ paraformaldehyde for $10 \mathrm{~min}$. Any residual cells were removed using a cotton swab then cells were stained with $0.1 \%$ crystal violet solution for $15 \mathrm{~min}$ at room temperature, washed with PBS three times and three visual fields were randomly imaged from each well using light microscopy(x400; Nikon Corporation).

Western blot analysis. Cells were cultured for $72 \mathrm{~h}$ then the expression levels of MAP1LC3A (1:1,000; ABclonal Biotech Co., Ltd.) and MTA1 proteins (1:500; Cell Signaling Technology, Inc.) were quantitatively measured. The total protein was extracted using a Bestbio protein extraction kit (AMSbio LLC) and collected. The protein concentration was quantitatively determined by bicinchoninic acid assay. Protein $(5 \mu \mathrm{l})$ was separated via SDS-PAGE on an $8 \%$ gel then transferred to a Nitrocellulose membrane (NC); Biotrace Ltd.) and the membrane was blocked with 5\% skim milk for $1 \mathrm{~h}$. Membranes were then incubated with horseradish peroxidase conjugated secondary antibody goat anti-mouse IgG (1:3,000; cat. no. LK2003; Sungene Biotech Co., Ltd.) for $1 \mathrm{~h}$ at room temperature. Following the addition of an ECL developer solution, an AI600 imaging system (GE Healthcare) was utilized to visualize the bands. $\beta$-actin $(1: 3,000$; cat. no. DKM9001T; Sungene Biotech Co., Ltd.) was used as the internal reference and incubated at $4^{\circ} \mathrm{C}$ overnight, and bands were analyzed using Quantity One analysis software (Quantity one v4.6.2.; Bio-Rad Laboratories, Inc.).

Reverse transcription-quantitative PCR (RT-qPCR). SKOV3 cells were incubated in six-well plates, cultured for $72 \mathrm{~h}$ then the RNA was extracted using TRIzol (Thermo Fisher Scientific, Inc.). RNA concentration and quality were measured. Total RNA was reverse transcribed to cDNA. qPCR was subsequently performed using a SYBR Premix Ex kit (Takara Bio, Inc.). The thermocycling conditions were as follows: Initial denaturation at $95^{\circ} \mathrm{C}$ for $30 \mathrm{sec} ; 40$ cycles of $95^{\circ} \mathrm{C}$ for $5 \mathrm{sec}$ and $60^{\circ} \mathrm{C}$ for $30 \mathrm{sec}$, with an amplification fragment of 148 bp in size. GAPDH was used as the internal reference. The intracellular expression level of MTA1 mRNA was quantified using the $2^{-\triangle \Delta C q}$ method (9). The primer sequences were as follows: MTA1 forward, 5'-GAGACCGAGTCGCTCAAG TCCTA-3' and reverse, 5'-AGTCGGGATGTCTGCTGGTA-3' and GAPDH forward, 5'-ACCTGACCTGCCGTAGAA-3' and reverse, 5'-TCCACCCTGTTGCTGTA-3'.

Statistical analysis. SPSS 19.0 statistical software was used for statistical analysis (IBM Corp.). All data are presented as the mean \pm standard deviation. Statistical significance between multiple groups was assessed using one-way analysis of variance followed by Student-Newman-Keuls post hoc test. The comparison of the data among different time points was conducted using repeated measures analysis of variance. $\mathrm{P}<0.05$ was considered to indicate statistical significance. 
Table I. Effect of metformin on the proliferation rate of SKOV3 cells.

\begin{tabular}{|c|c|c|c|c|c|c|}
\hline \multirow[b]{2}{*}{ Concentration $(\mathrm{mmol} / \mathrm{l})$} & \multicolumn{3}{|c|}{ Treatment duration (h) } & \multirow[b]{2}{*}{ Total } & \multirow[b]{2}{*}{ F-value } & \multirow[b]{2}{*}{ P-value } \\
\hline & 24 & 48 & 72 & & & \\
\hline 2.5 & $10.80 \pm 1.78$ & $18.41 \pm 1.94$ & $22.20 \pm 1.19$ & $17.16 \pm 4.03$ & 49.673 & 0.001 \\
\hline 5 & $16.25 \pm 1.60$ & $23.01 \pm 2.76$ & $27.62 \pm 1.62$ & $22.29 \pm 4.56$ & 38.336 & 0.001 \\
\hline 10 & $20.30 \pm 1.69$ & $27.95 \pm 2.69$ & $33.30 \pm 3.56$ & $27.18 \pm 5.03$ & 28.195 & 0.001 \\
\hline SUM & $15.77 \pm 3.28$ & $23.12 \pm 3.90$ & $27.71 \pm 4.13$ & & $150.09^{\mathrm{a}}$ & $0.001^{\mathrm{a}}$ \\
\hline F-value & 101.121 & 31.078 & 67.157 & $45.284^{\mathrm{a}}$ & $5.089^{\mathrm{b}}$ & $0.038^{\mathrm{b}}$ \\
\hline P-value & 0.001 & 0.001 & 0.001 & $0.001^{\mathrm{a}}$ & & \\
\hline
\end{tabular}

${ }^{\mathrm{a}} \mathrm{P}<0.05 \mathrm{vs} .2 .5 \mathrm{mmol} / \mathrm{l}$ group, $5 \mathrm{mmol} / \mathrm{l}$ group and $10 \mathrm{mmol} / \mathrm{l}$ group. ${ }^{\mathrm{b}} \mathrm{P}<0.05$. vs. 24,48 and $72 \mathrm{~h}$.

Table II. Effect of different concentrations of metformin on the apoptosis rate of SKOV3 cells.

\begin{tabular}{|c|c|c|c|c|c|c|}
\hline \multirow[b]{2}{*}{ Group } & \multicolumn{3}{|c|}{ Concentration of metformin (mmol/l) } & \multirow[b]{2}{*}{10} & \multirow[b]{2}{*}{ F-value } & \multirow[b]{2}{*}{ P-value } \\
\hline & 0 & 2.5 & 5 & & & \\
\hline Apoptosis rate $(\%)$ & $3.01 \pm 1.51$ & $10.56 \pm 1.08^{\mathrm{a}}$ & $31.31 \pm 2.21^{\mathrm{a}, \mathrm{b}}$ & $35.60 \pm 1.24^{\mathrm{a}-\mathrm{c}}$ & 373.819 & 0.001 \\
\hline
\end{tabular}

${ }^{\mathrm{a}} \mathrm{P}<0.05$ vs. $0 \mathrm{mmol} / 1$ group. ${ }^{\mathrm{b}} \mathrm{P}<0.05$ vs. $2.5 \mathrm{mmol} / 1$ group. ${ }^{\mathrm{c}} \mathrm{P}<0.05$ vs. $5 \mathrm{mmol} / \mathrm{l}$ group.

\section{Results}

Metformin inhibits cell proliferation in a dose-dependent manner. Administration of metformin exerted an inhibitory effect on SKOV3 proliferation in a concentration-dependent manner $(\mathrm{P}<0.05$; Table I). The inhibitory effect of metformin on cell proliferation also significantly increased with duration of metformin treatment $(\mathrm{P}<0.05$; Table I).

Metformin significantly increases cell apoptosis in a dose-dependent manner. SKOV3 cells were stained with Annexin V-FITC/PI and analyzed by flow cytometry for cellular apoptosis. At 48 h, SKOV3 cells treated with different concentrations of metformin displayed significantly enhanced apoptosis rate compared with the untreated control (Table II). The apoptosis rate of SKOV3 cells was significantly increased with increasing concentration of metformin $(\mathrm{P}<0.05$; Fig. 1 ; Table II).

Metformin promotes autophagy. Electron microscopy demonstrated that there was no autophagosome formation in the SKOV3 cells of the control group (Fig. 2A). Following treatment with $10 \mathrm{mmol} / 1$ metformin for $72 \mathrm{~h}$, multiple autophagosomes were observed in the SKOV3 cells, which suggested that administration of metformin promoted autophagy of ovarian cancer SKOV3 cells (Fig. 2B)

Metformin inhibits cell migration in a dose-dependent manner. SKOV3 cells treated with metformin for 24 and $48 \mathrm{~h}$ demonstrated significantly decreased cell migration into the scratch gap compared with the control group $(\mathrm{P}<0.05$; Fig. 3; Table III). There was no statistical significance in cell
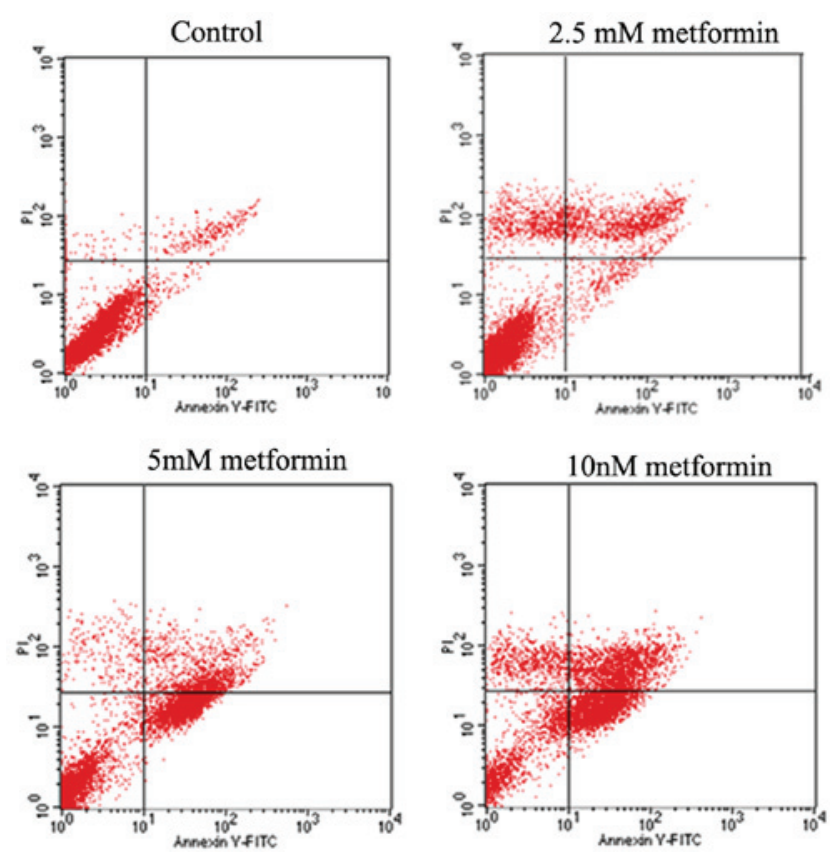

Figure 1. Cell apoptosis was examined through flow cytometry. Flow cytometry analysis of cell apoptosis.

migration distance between the 2.5 and $5 \mathrm{mmol} / 1$ metformin treatment groups following treatment with metformin for $24 \mathrm{~h}$ (P>0.05; Fig. 3; Table III). Cell migration was significantly decreased with increasing concentration of metformin at 24 and $48 \mathrm{~h}(\mathrm{P}<0.05$; Fig. 2; Table III). Cell migration increased with duration of metformin intervention $(\mathrm{P}<0.05$; Fig. 2; Table III). 


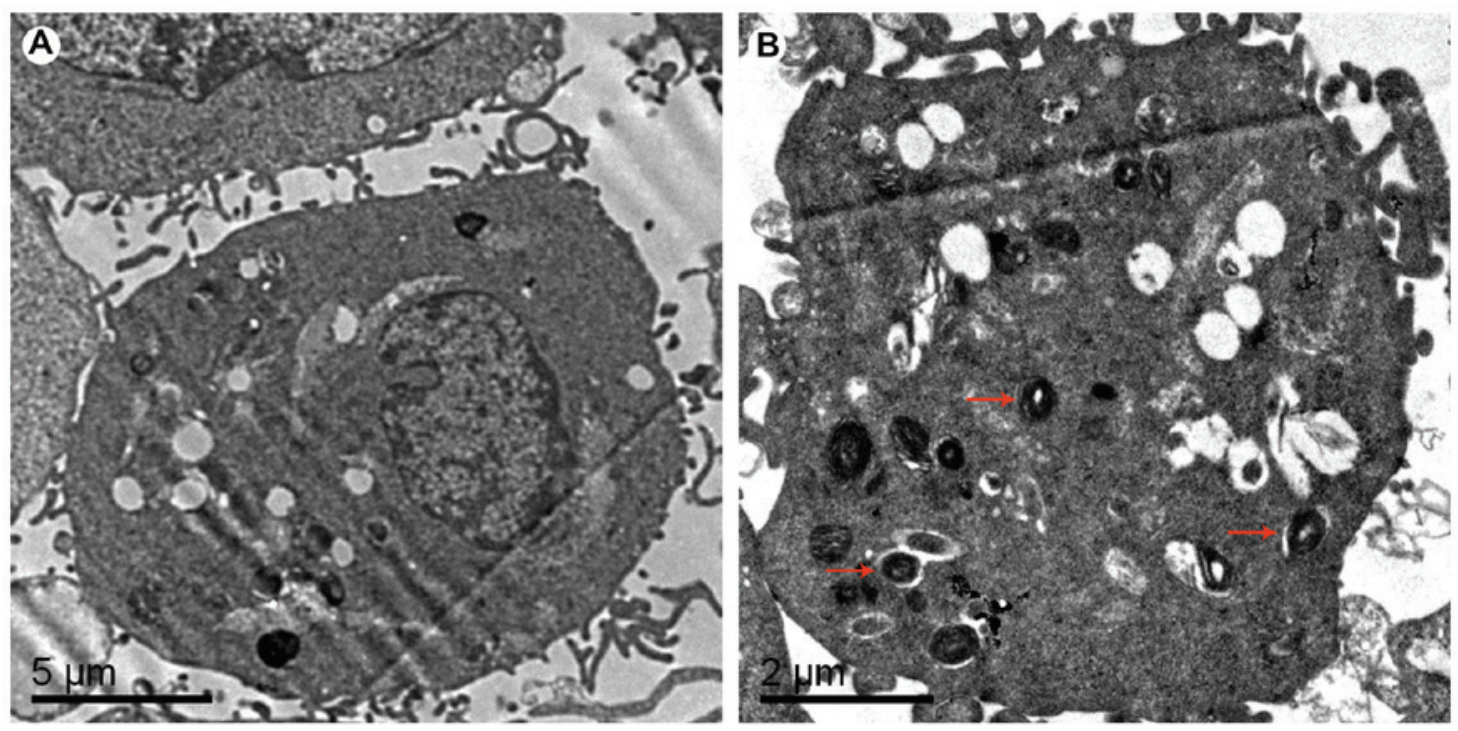

Figure 2. Autophagy in SKOV3 cells determined by electron microscopy. Micrographs of cells following treatment with (A) 0 and (B) $10 \mathrm{mmol} / 1 \mathrm{metformin}$ for $72 \mathrm{~h}$. Red arrows indicate autophagosomes.

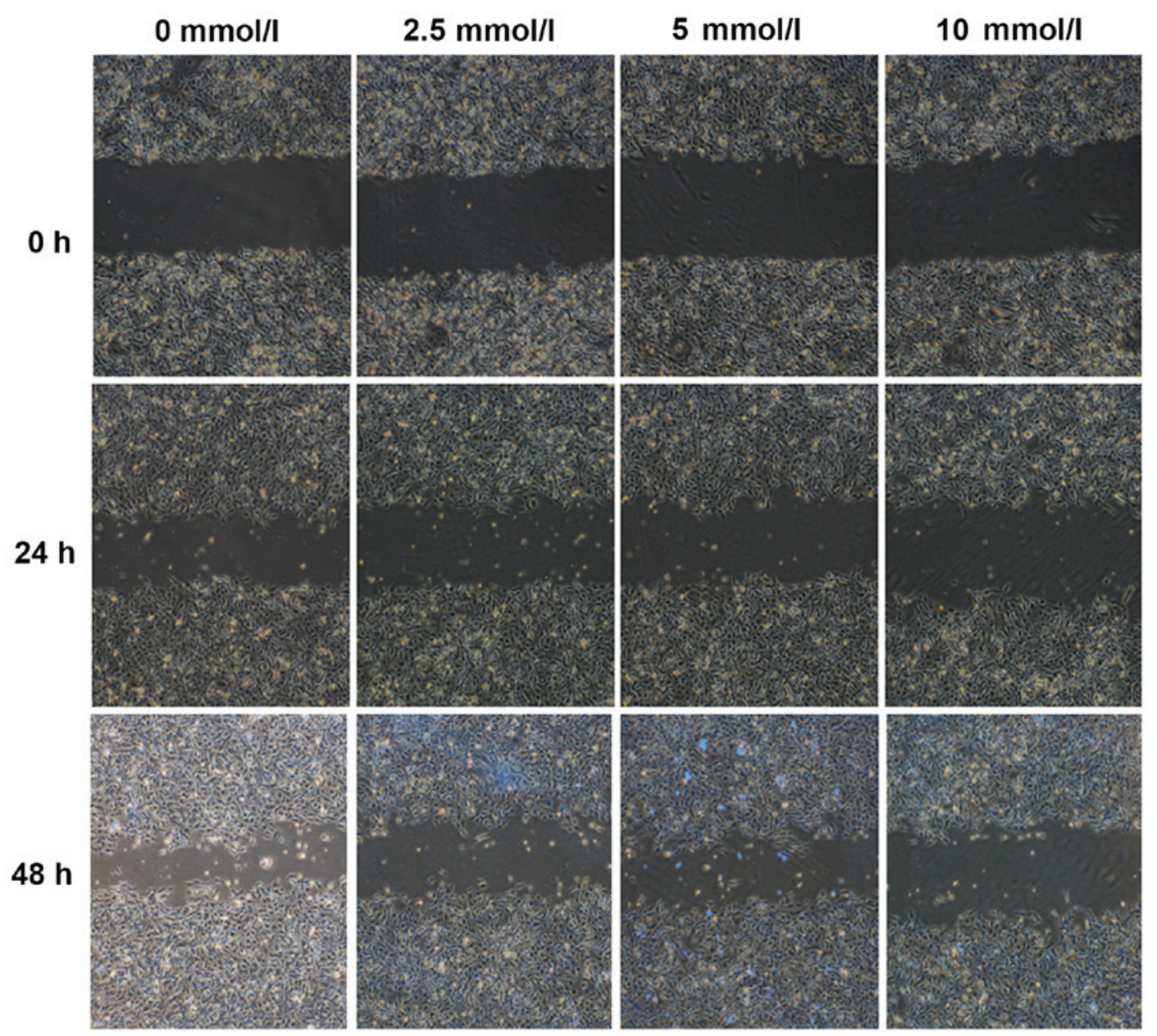

Figure 3. Effect of different concentrations of metformin $(0,2.5,5$ and $10 \mathrm{mmol} / \mathrm{l})$ on the migration ability of SKOV3 cells at 0,24 and $48 \mathrm{~h}$. Magnification, $\mathrm{x} 40$.

Metformin inhibits cell invasion in a dose-dependent manner. In the control group, the quantity of transmembrane cells was calculated as $86.6 \pm 5.01$, which was significantly higher compared with the $2.5 \mathrm{mmol} / \mathrm{l}(58.4 \pm 3.58), 5 \mathrm{mmol} / \mathrm{l}$
$(42.7 \pm 4.97)$ and $10 \mathrm{mmol} / \mathrm{l}(15.0 \pm 4.30)$ metformin intervention groups (Fig. 3). Results suggested that the number of invading cells was significantly reduced with increasing concentration of metformin ( $\mathrm{P}<0.01$; Fig. 4). 
Table III. Effect of different concentrations of metformin on mean scratch distance.

\begin{tabular}{|c|c|c|c|c|c|c|}
\hline \multirow[b]{2}{*}{ Group } & \multicolumn{3}{|c|}{ Mean scratch distance $(\mu \mathrm{m})$} & \multirow[b]{2}{*}{ Total } & \multirow[b]{2}{*}{ F-value } & \multirow[b]{2}{*}{ P-value } \\
\hline & $0 \mathrm{~h}$ & $24 \mathrm{~h}$ & $48 \mathrm{~h}$ & & & \\
\hline Control group & $584.31 \pm 6.73$ & $468.27 \pm 7.71$ & $389.17 \pm 6.86$ & $480.58 \pm 98.15$ & $103.72 \pm 82.21$ & 0.001 \\
\hline $2.5 \mathrm{mmol} / \mathrm{l}$ & $625.29 \pm 16.20$ & $546.46 \pm 6.50$ & $464.23 \pm 8.71$ & $545.32 \pm 80.53$ & $79.96 \pm 68.85$ & 0.001 \\
\hline $5 \mathrm{mmol} / \mathrm{l}$ & $607.21 \pm 4.44$ & $535.23 \pm 14.09$ & $481.36 \pm 2.63$ & $539.65 \pm 65.46$ & $67.55 \pm 56.24$ & 0.001 \\
\hline $10 \mathrm{mmol} / \mathrm{l}$ & $682.75 \pm 31.53$ & $633.65 \pm 8.31$ & $584.70 \pm 11.32$ & $633.70 \pm 49.02$ & $49.05 \pm 45.35$ & 0.001 \\
\hline Total & 624.89 & 545.90 & 478.65 & & $1,040.52$ & 0.001 \\
\hline F-value & $584.31 \pm 6.73$ & $36.016^{\mathrm{a}}$ & $87.819^{\mathrm{b}}$ & 209.52 & $23.39^{c}$ & $0.001^{\mathrm{c}}$ \\
\hline P-value & & $0.001^{\mathrm{a}}$ & $0.001^{\mathrm{b}}$ & 0.001 & & \\
\hline
\end{tabular}

${ }^{\mathrm{a}} \mathrm{P}<0.05$ vs. control group at $24 \mathrm{~h} .{ }^{\mathrm{b}} \mathrm{P}<0.05$ vs. control group at $48 \mathrm{~h} .{ }^{\mathrm{c}} \mathrm{P}<0.05$ vs. control group at $0 \mathrm{~h}$.
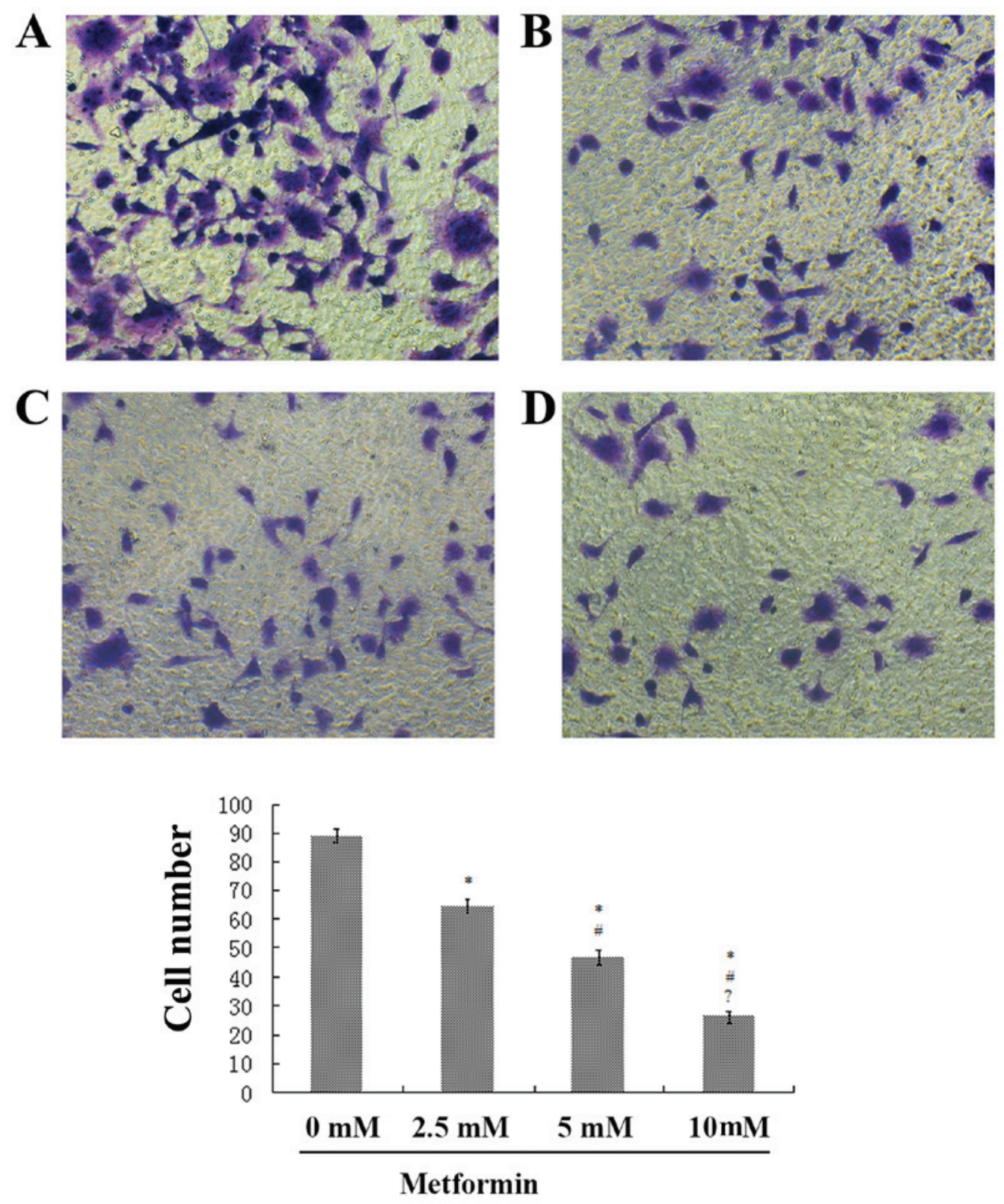

Figure 4. Effect of different concentrations of metformin on the invasion ability of SKOV 3 cells. Transwell assay micrographs for (A) 0 , (B) 2.5 , (C) 5 and (D) $10 \mathrm{mmol} / 1$ metformin treatment. Magnification, $\mathrm{x} 200$. ${ }^{\text {}} \mathrm{P}<0.05$ vs. $0 \mathrm{mM}$; ${ }^{\prime} \mathrm{P}<0.05$ vs. $2 . \mathrm{mM}$; ${ }^{\mathrm{P}} \mathrm{P}<0.05$ vs. $5 \mathrm{mM}$. 

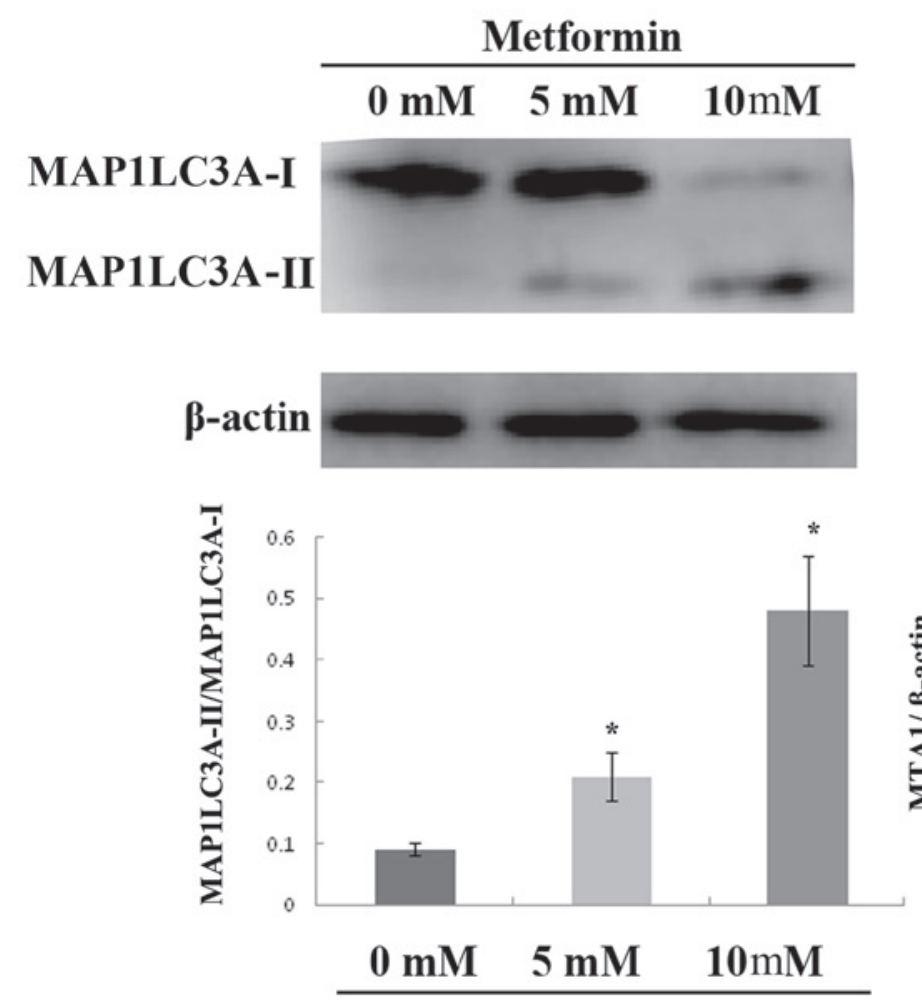

Metformin
Metformin

\section{$0 \mathrm{mM} 2.5 \mathrm{mM} 5 \mathrm{mM} 10 \mathrm{mM}$}
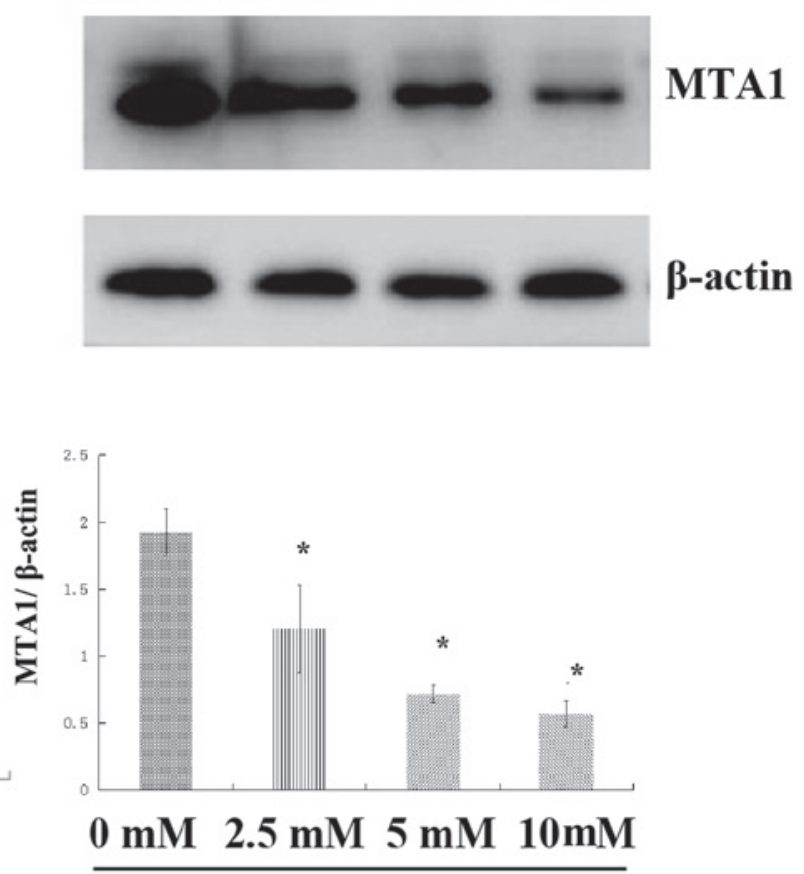

Metformin

Figure 5. Effect of metformin on protein expression levels of MAP1LC3A and MTA1 determined by western blot analysis. "P<0.05 vs. 0 mM metformin. MAP1LC3A, microtubule-associated protein 1 light chain 3- $\alpha$; MTA1, metastasis-associated 1.

Metformin significantly decreases MAPILC3A-II and MTA1 protein expression whilst increasing MAPILC3A-I protein expression. Following treatment with metformin for $72 \mathrm{~h}$, the expression level of intracellular MAP1LC3A-II protein was significantly upregulated; Fig. 5A). No statistical significance was observed in MAP1LC3A-II protein expression between the control and $5 \mathrm{mmol} / 1$ metformin treatment groups (Fig. 5). MAP1LC3A-II protein expression was significantly upregulated with the increasing metformin concentration (Fig. 5). MTA1 protein expression was decreased with increasing metformin concentration. Protein expression was $1.92 \pm 0.18$ in the control group $1.26 \pm 0.32$ in the $2.5 \mathrm{mmol} / 1$ metformin group, $0.72 \pm 0.07$ in the $5 \mathrm{mmol} / \mathrm{l}$ metformin group and $0.56 \pm 0.10$ in the $10 \mathrm{mmol} / 1$ metformin group (Fig. 5). There was no statistical significance in MTA1 protein expression amongst different concentrations groups (Fig. 5).

Metformin significantly decreases MTA1 mRNA expression. Compared with the control group, the expression levels of MTA1 mRNA in all experimental groups were significantly downregulated (Fig. 6). There was no statistical difference in MTA1 mRNA expression amongst the different metformin concentration groups (Fig. 6).

\section{Discussion}

Ovarian cancer is a heterogeneous disease with inter- and intra-tumor heterogeneity that has a high mortality rate (8). In spite of advancements in surgical and radiation therapy, chemotherapy remains a vital therapeutic option for different types of

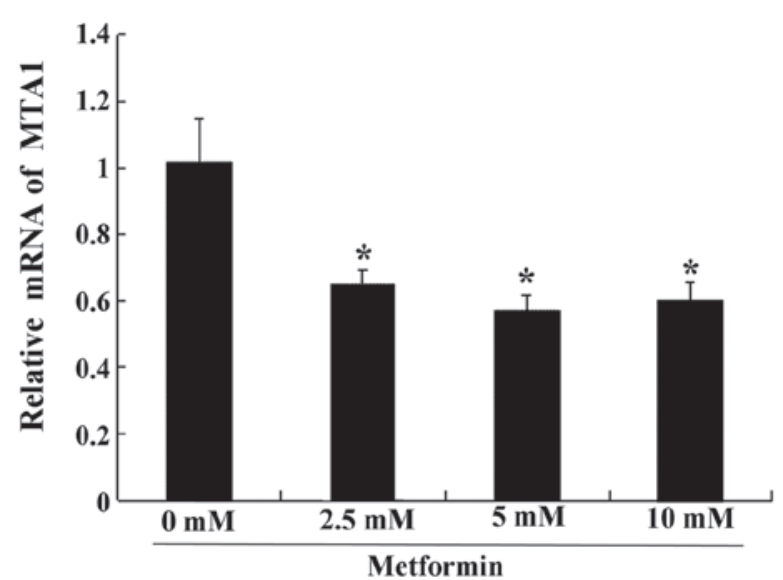

Figure 6. Effect of different concentrations of metformin $(0,2.5,5$ and $10 \mathrm{mmol} / \mathrm{l})$ on the expression of MTA1 mRNA. "P<0.05 vs. control. MTA1, metastasis-associated 1.

malignant tumors. Chemotherapy resistance and lack of novel treatments means that there is an urgent need for comprehensive genomic analysis to identify the genetic abnormalities in ovarian tumors, which can affect the pathophysiology and chemotherapeutic responses of ovarian patients $(10,11)$.

Metformin is widely applied in clinical practice and has minimal adverse events. It has been reported that administration of metformin significantly suppresses the proliferation of multiple chemo-responsive and resistant ovarian cancer cell lines, leads to cell cycle arrest, decreases cyclin D1 and increases cyclin dependent kinase inhibitor 1A (p21) protein 
expression (12). In addition, metformin induces an inhibitory effect on OVCAR-3 and OVCAR-4 ovarian cancer cell proliferation in a time- and dose-dependent manner. The drug also induces apoptosis by activating caspases $3 / 7$ and downregulating Bcl-2 and Bcl-xL expression $(13,14)$. A previous study demonstrated that metformin-induced lactate accumulation limits the tumor-killing potential. Dichloroacetate and metformin synergistically suppress the growth of xenograft ovarian tumors and can overcome the limit of lactate accumulation (15).

In the present study, the effect of metformin administration on the growth and proliferation of ovarian cancer SKOV3 cells was investigated. Results demonstrated that metformin inhibited the proliferation, migration and invasion of SKOV3 cells, and also induced cellular apoptosis and autophagy. It was hypothesized that the effect of metformin involves a number of mechanisms. Firstly, metformin reduces blood glucose levels in the environment where tumor cells survive, decreases the cellular nutrients to the malignant tumors and thereby suppresses the progression of malignant tumors (16). Although insulin exerts a higher glucose-lowering effect compared with metformin, insulin likely promotes the progression of malignant tumors as it activates insulin-like growth factor 1 receptor (17). Metformin enhances the sensitivity of peripheral tissues towards insulin, strengthens cellular uptake and utilization of insulin (18), reduces insulin serum levels and decreases the activation of IGF-1, thereby exerting an anti-malignant tumor effect (19). Metformin likely decreases the nutrients available to tumor cells through reducing the blood glucose level; however, it may also lower the serum level of insulin preventing the activation of related signaling pathways and inhibiting the effect of insulin on promoting the progression of malignant tumors (20). Secondly, metformin directly affects the AMPK-related signaling pathway, has a vital role in certain steps of tumor cell growth and suppresses the growth and proliferation of tumor cells (19). AMPK is an enzyme involved in cellular energy homeostasis. It belongs to a highly conserved eukaryotic protein family and its orthologues are serine threonine protein kinase and SNF1-related protein kinase in yeast and plants (21). When AMPK phosphorylates acetyl-CoA carboxylase 1 or sterol regulatory element-binding protein $1 \mathrm{c}$, it inhibits synthesis of fatty acids, cholesterol and triglycerides, and activates fatty acid uptake and $\beta$-oxidation (22). In addition, AMPK affects cell growth, proliferation, the cell cycle, invasion, migration and apoptosis (23). Metformin exerts an anti-malignant tumor effect through the AMPK signaling pathway where it can activate the $\mathrm{p} 53$ protein, which coordinates with p21 protein to identify intracellular DNA injury, suppress cellular proliferation and inhibit the progression of malignant tumors (24). Metformin plays an anti-tumor role by inhibiting the expression of mTOR (25). The AMPK/mTOR signaling pathway serves a crucial role protein transcription, cell proliferation, apoptosis and autophagy, and, therefore, can regulate the growth metabolism of tumor cells (26). Furthermore, Rattan et al (12) demonstrated that metformin induces stagnation of the cell cycle. Cyclin D1 is required for progression through the G1 cell cycle (27). Metformin activates the AMPK signaling pathway and the p53-p21 axis, and blocks the G1/S stage of the cell cycle (5). In addition, metformin activates the AMPK/glycogen synthase kinase 3- $\beta$ signaling pathway, induces degradation of the cycle protein D1 and consequently induces stagnation of the cell cycle (3).

Autophagy is directly correlated with the progression and apoptosis of malignant tumors. Previous studies have demonstrated that low levels of autophagy are associated with tumor progression $(28,29)$. Increasing the autophagy level contributes to reducing the invasion and migration capabilities of tumor cells (30). Detection of MAP1LC3A expression can indicate cellular autophagy. MAP1LC3A consists of two forms; MAP1LC3A-I and MAP1LC3A-II. The expression level of MAP1LC3A-II and the ratio of MAP1LC3A-II/MAP1LC3A-I are positively correlated with the quantity of autophagosomes (31). In the present study, MAP1LC3A-II was utilized as the biomarker for the assessment of cellular autophagy. The expression level of MAP1LC3A-II in the SKOV3 cells was upregulated with increasing concentration of metformin treatment whilst the expression level of MAP1LC3A-I was downregulated, which indicated that metformin strengthened cellular autophagy of SKOV3 cells. These results were consistent with the subsequent electron microscopy findings. When taking into account the Transwell chamber assay and scratch test results, it may be hypothesized that a high level of autophagy is able to inhibit cellular invasion and migration, which is consistent with the results obtained by Valente et al (30).

MTA1 is a cytokine associated with cellular metastasis and positively correlated with the invasion and migration ability of tumor cells (32-34). In the present study, the healing ability of the treated cells in the metformin intervention groups was significantly decreased, and the cellular invasion ability was considerably diminished in a dose-dependent manner, which is consistent with previous findings (35). Following treatment with metformin, the mRNA expression of MTA1 was downregulated, which suggested that the inhibition of cell invasion and migration may be associated with the MTA1 levels. Studies have demonstrated that MTA proteins are a small family of transcriptional coregulators that are closely associated with tumor metastasis and regulate genetic transcription through affecting the chromatin status $(36,37)$. MTA1 expression is closely correlated with the aggressiveness of several cancers including breast, liver, colon, pancreas, prostate, blood, esophageal and gastro-intestinal $(36,37)$.

NF- $\mathrm{KB}$ is a key protein belonging to the family of eukaryotic transcription factor proteins that regulates the immune and inflammatory response. Recent research has demonstrated that metformin can downregulate the expression levels of NF- $\mathrm{KB}$ in multiple types of tumor cells (38). Bui-Nguyen et al (39) proposed that MTA1 promoter contains 5 common sites of NF- $\kappa B$. Among them, RELA proto-oncogene can directly bind and stimulate MTA1 transcription. These findings collectively indicate that the NF- $\kappa \mathrm{B}$ signaling pathway may regulate MTA1 transcription. However, the mechanism underlying the effect of metformin on MTA1 requires further investigation.

In conclusion, the present findings demonstrated that administration of metformin suppressed the invasion and migration capabilities of epithelial ovarian cancer cells, and reduced cell proliferation. The downregulation of MTA1 induced by metformin may contribute to ovarian cancer inhibition in vitro. The complete underlying mechanism of 
metformin on ovarian cancer cells remains to be further elucidated by subsequent investigations.

\section{Acknowledgements}

Not applicable.

\section{Funding}

This study was supported by The Outstanding Clinical Medical Talents Project of Hebei Province (grant. no. 2016-361036).

\section{Availability of data and materials}

The datasets used and/or analyzed during the current study are available from the corresponding author on reasonable request.

\section{Authors' contributions}

YC proposed and designed the study. GZ and DL performed the literature research and experimental studies. JB peformed data analysis and manuscript preparation. All authors read and approved the final manuscript

\section{Ethics approval and consent to participate}

Not applicable.

\section{Patient consent for publication}

Not applicable.

\section{Competing interests}

The authors declare that they have no competing interests.

\section{References}

1. Liu H, Scholz C, Zang C, Schefe JH, Habbel P, Regierer AC, Schulz CO, Possinger K and Eucker J: Metformin and the mTOR inhibitor everolimus (RAD001) sensitize breast cancer cells to the cytotoxic effect of chemotherapeutic drugs in vitro. Anticancer Res 32: 1627-1637, 2012.

2. Cheng K and Hao M: Metformin inhibits TGF- $\beta 1$-induced epithelial-to-mesenchymal transition via PKM2 relative-mTOR/p70s6k signaling pathway in cervical carcinoma cells. Int J Mol Sci 17: E2000, 2016.

3. GwakH,Kim Y,AnH,Dhanasekaran DN and Song YS: Metformin induces degradation of cyclin D1 via AMPK/GSK3beta axis in ovarian cancer. Mol Carcinog 56: 349-358, 2017.

4. Gajjar K, Ogden G, Mujahid MI and Razvi K: Symptoms and risk factors of ovarian cancer: A survey in primary care. ISRN Obstet Gynecol 2012: 754197, 2012.

5. Kasznicki J, Sliwinska A and Drzewoski J: Metformin in cancer prevention and therapy. Ann Transl Med 2: 57, 2014.

6. Pollak M: The insulin and insulin-like growth factor receptor family in neoplasia: An update. Nat Rev Cancer 12: 159-169, 2012.

7. Okubo K, Isono M, Asano T and Sato A: Metformin augments panobinostat's anti-bladder cancer activity by activating AMP-activated protein kinase. Transl Oncol 12: 669-682, 2019.

8. Moon HS, Kim B, Gwak H, Suh DH and Song YS: Autophagy and protein kinase RNA-like endoplasmic reticulum kinase $($ PERK)/eukaryotic initiation factor 2 alpha kinase (eIF2 $\alpha$ ) pathway protect ovarian cancer cells from metformin-induced apoptosis. Mol Carcinog 55: 346-356, 2016.
9. Livak KJ and Schmittgen TD: Analysis of relative gene expression data using real-time quantitative PCR and the 2(-Delta Delta C(T)) method. Methods 25: 402-408, 2001.

10. Binju M, Padilla MA, Singomat T, Kaur P, Suryo Rahmanto Y, Cohen PA and Yu Y: Mechanisms underlying acquired platinum resistance in high grade serous ovarian cancer - a mini review. Biochim Biophys Acta Gen Subj 1863: 371-378, 2019.

11. Freimund AE, Beach JA, Christie EL and Bowtell DDL: Mechanisms of drug resistance in high-grade serous ovarian cancer. Hematol Oncol Clin North Am 32: 983-996, 2018.

12. Rattan R, Giri S, Hartmann LC and Shridhar V: Metformin attenuates ovarian cancer cell growth in an AMP-kinase dispensable manner. J Cell Mol Med 15: 166-178, 2011.

13. Yasmeen A, Beauchamp MC, Piura E, Segal E, Pollak M and Gotlieb WH: Induction of apoptosis by metformin in epithelial ovarian cancer: Involvement of the Bcl-2 family proteins. Gynecol Oncol 121: 492-498, 2011.

14. Gotlieb WH, Saumet J, Beauchamp MC, Gu J, Lau S, Pollak MN and Bruchim I: In vitro metformin anti-neoplastic activity in epithelial ovarian cancer. Gynecol Oncol 110: 246-250, 2008.

15. Li B, Li X, Ni Z, Zhang Y, Zeng Y, Yan X, Huang Y, He J, Lyu X, Wu Y, et al: Dichloroacetate and metformin synergistically suppress the growth of ovarian cancer cells. Oncotarget 7: 59458-59470, 2016.

16. Wheaton WW, Weinberg SE, Hamanaka RB, Soberanes S, Sullivan LB, Anso E, Glasauer A, Dufour E, Mutlu GM, Budigner GS and Chandel NS: Metformin inhibits mitochondrial complex I of cancer cells to reduce tumorigenesis. Elife 3: e02242, 2014.

17. Ter Braak B, Siezen CL, Lee JS, Rao P, Voorhoeve C, Ruppin E, van der Laan JW and van de Water B: Insulin-like growth factor 1 receptor activation promotes mammary gland tumor development by increasing glycolysis and promoting biomass production. Breast Cancer Res 19: 14, 2017.

18. Bailey CJ and Turner RC: Metformin. N Engl J Med 334: 574-579, 1996.

19. Kheirandish M, Mahboobi H, Yazdanparast M, Kamal W and Kamal MA: Anti-cancer effects of metformin: Recent evidences for its role in prevention and treatment of cancer. Curr Drug Metab 19: 793-797, 2018.

20. Sosnicki S, Kapral M and Weglarz L: Molecular targets of metformin antitumor action. Pharmacol Rep 68: 918-925, 2016.

21. Coccetti P, Nicastro R and Tripodi F: Conventional and emerging roles of the energy sensor Snf1/AMPK in saccharomyces cerevisiae. Microb Cell 5: 482-494, 2018.

22. Ikhlas S and Ahmad M: Metformin: Insights into its anticancer potential with special reference to AMPK dependent and independent pathways. Life Sci 185: 53-62, 2017.

23. Faubert B, Vincent EE, Poffenberger MC and Jones RG: The AMP-activated protein kinase (AMPK) and cancer: Many faces of a metabolic regulator. Cancer Lett 356: 165-170, 2015.

24. Cerezo M, Tichet M, Abbe P, Ohanna M, Lehraiki A, Rouaud F, Allegra M, Giacchero D, Bahadoran P, Bertolotto C, et al: Metformin blocks melanoma invasion and metastasis development in AMPK/p53-dependent manner. Mol Cancer Ther 12: 1605-1615, 2013.

25. Luo Q, Hu D, Hu S, Yan M, Sun Z and Chen F: In vitro and in vivo anti-tumor effect of metformin as a novel therapeutic agent in human oral squamous cell carcinoma. BMC Cancer 12: 517, 2012.

26. Mizushima N and Klionsky DJ: Protein turnover via autophagy: Implications for metabolism. Ann Rev Nutr 27: 19-40, 2007.

27. Baldin V, Lukas J, Marcote MJ, Pagano M and Draetta G: Cyclin $\mathrm{D} 1$ is a nuclear protein required for cell cycle progression in G1. Genes Dev 7: 812-821, 1993.

28. Galluzzi L, Pietrocola F, Bravo-San Pedro JM, Amaravadi RK, Baehrecke EH, Cecconi F, Codogno P, Debnath J, Gewirtz DA, Karantza V, et al: Autophagy in malignant transformation and cancer progression. EMBO J 34: 856-880, 2015.

29. Mathew R, Kongara S, Beaudoin B, Karp CM, Bray K, Degenhardt K, Chen G, Jin S and White E: Autophagy suppresses tumor progression by limiting chromosomal instability. Genes Dev 21: 1367-1381, 2007.

30. Valente G, Morani F, Nicotra G, Fusco N, Peracchio C, Titone R, Alabiso O, Arisio R, Katsaros D, Benedetto C and Isidoro C: Expression and clinical significance of the autophagy proteins BECLIN 1 and LC3 in ovarian cancer. Biomed Res Int 2014: 462658, 2014. 
31. Giatromanolaki AN, Charitoudis GS, Bechrakis NE, Kozobolis VP, Koukourakis MI, Foerster MH and Sivridis EL: Autophagy patterns and prognosis in uveal melanomas. Mod Pathol 24: 1036-1045, 2011.

32. Li Y, Chao Y, Fang Y, Wang J, Wang M, Zhang H, Ying M, Zhu X and Wang H: MTA1 promotes the invasion and migration of non-small cell lung cancer cells by downregulating miR-125b. J Exp Clin Cancer Res 32: 33, 2013.

33. Marzook H, Li DQ, Nair VS, Mudvari P, Reddy SD, Pakala SB, Santhoshkumar TR, Pillai MR and Kumar R: Metastasis-associated protein 1 drives tumor cell migration and invasion through transcriptional repression of RING finger protein 144A. J Biol Chem 287: 5615-5626, 2012.

34. Wang H, Fan L, Wei J, Weng Y, Zhou L, Shi Y, Zhou W, Ma D and Wang C: Akt mediates metastasis-associated gene 1 (MTA1) regulating the expression of E-cadherin and promoting the invasiveness of prostate cancer cells. PloS One 7: e46888, 2012

35. Mei ML, Li QL, Chu CH, Yiu CK and Lo EC: The inhibitory effects of silver diamine fluoride at different concentrations on matrix metalloproteinases. Dent Mater 28: 903-908, 2012.
36. Kumar R, Wang RA and Bagheri-Yarmand R: Emerging roles of MTA family members in human cancers. Semin Oncol 30 (5 Suppl 16): 30-37, 2003

37. Malisetty VL, Penugurti V, Panta P, Chitta SK and Manavathi B: MTA1 expression in human cancers-clinical and pharmacological significance. Biomed Pharmacother 95: 956-964, 2017.

38. Zhou H, Xu X, Xun Q, Yu D, Ling J, Guo F, Yan Y, Shi J and $\mathrm{Hu}$ Y: microRNA-30c negatively regulates endometrial cancer cells by targeting metastasis-associated gene-1. Oncol Rep 27: 807-812, 2012.

39. Bui-Nguyen TM, Pakala SB, Sirigiri RD, Xia W, Hung MC, Sarin SK, Kumar V, Slagle BL and Kumar R: NF-kappaB signaling mediates the induction of MTA1 by hepatitis B virus transactivator protein HBx. Oncogene 29: 1179-1189, 2010.

(i) (2) This work is licensed under a Creative Commons Attribution-NonCommercial-NoDerivatives 4.0 International (CC BY-NC-ND 4.0) License. 